\title{
HSI種多様性に基づく流域の 遺伝的多様性空間分布の予測 PREDICTION OF SPATIAL GENETIC DIVERSITY DISTRIBUTION FROM HSI BASED SPECIES DIVERSITY
}

\author{
糠澤 桂 ${ }^{1}$ 風間 聡 $^{2} \cdot$ 渡辺 幸三 $^{3}$ \\ Kei NUKAZAWA, So KAZAMA, Kozo WATANABE \\ 1学生会員 修 (工) 東北大学大学院工学研究科 (广9980-8579 仙台市青葉区荒巻字青葉6-6-06) \\ 2正会員 博 (工) 東北大学大学院工学研究科 (广980-8579 仙台市青葉区荒巻字青葉6-6-06) \\ ${ }^{3}$ 正会員 博 (工) 愛媛大学大学院理工学研究科 (广790-8577 愛媛県松山市文京町3番)
}

\begin{abstract}
In accordance with a most recent report in discipline "landscape genetics", simulation studies to predict spatial genetic variation are urgently required. We evaluated relationships between genetic diversities of caddisfly Hydropsyche orientalis and species diversity calculated from Habitat Suitability Index (HSI) of aquatic animals and discussed outliers in the correlation diagrams in the Natori River basin located at the middle of Miyagi prefecture. Omitting two significant outliers, we developed spatial genetic diversity distribution maps on the basis of linear regression models in the correlation diagrams. At the catchment scale, the longitudinal distribution of genetic diversity had high peak in the middle stream. The result is identical with the observed pattern of genetic diversity for the species. The prediction has advantages which can be applied to future planning in respect of dam removal, urban planning, and zoning in view of genetic diversity.
\end{abstract}

Key words: distributed runoff model, habitat suitability index, Hydropsyche orientalis, Landscape genetics, Trichoptera

\section{1. はじめに}

生物の多様性に関する条約（CBD/COP） ${ }^{1)}$ において, 種多様性と遺伝的多様性の国際的保全・持続的利用が提 言されている. 種多様性は種数や個体数を用いた多様度 指数により表現され，遺伝的多様性は同種個体間におけ るDNA塩基配列の多型を生物実験により検知して数值 化出来る. Vellend とGeberによれば，種多様性と遺伝的 多様性はそれぞれ独立に局所的環境の影響により変動す ることが知られている2). また，両多様性の一般的な関 係性は正の相関と報告されている2).

景観遺伝学 (Landscape genetics) は遺伝的多様性の空 間的な変動を, その地域の地理・地勢等と関連付けて評 価する学問領域である ${ }^{3)}$. 景観遺伝学において, 遺伝的 多様性を緯経度や気温との関係性からモデル化する事例 は存在する (例えば, Jumpら 2006 ${ }^{4)}$, Mariacら 20105) が, 年間の水理変動と関連付ける研究はこれまで存在し
ない. 既報のにおいて，これまでの実践的研究の限界を 指摘し, 今後, 遺伝的多様性の時空間的な変動を考慮す るモデルが求められると結論付けている.

流域における生態学的モデリングの事例として, HSI（Habitat Suitability Index）モデルを利用して淡水魚 の産卵条件や流量の適正範囲を推定する研究等が頻繁に

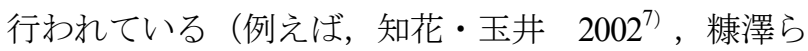
$2011^{8)}$ ) . HSIは物理環境より対象生物の生息場適性度 を推定する構造を持つ. 風間ら ${ }^{9}$ はHSIモデルより種多 様性を推定し，空間的に補間して流域全域一拡張してい る. 一方，遺伝的多様性の評価は，最近になり実践的な 研究が増加している ${ }^{10)}$ 12). しかし, 従来の現地調査に 基づく遺伝的多様性の評価は一般に局所的である.これ は，流域全域に渡る調査は時間・コストの関係上困難な ことが原因である. 遺伝的多様性のモデル化について, 時空間的に連続な遺伝的多様性の分布を推定出来るため, 現地調査や室内実験の省力化・コスト削減が期待出来る. 糠澤ら ${ }^{13)}$ はHSIに基づいて算定された河川生物の種多 
様性（HSI種多様性）と水生昆虫の遺伝的多様性の関係 性を評価している。 HSIモデルは6種水生生物に関して, 分布型流出モデル ${ }^{14)}$ から算定した水理データと地理 データを基に構築されている. 本報告によると, ウル マーシマトビケラ (Hydropsyche orientalis) 個体群の遺 伝的多様性はHSI種多様性と有意な正の相関を有するこ とが確認されている.この結果に基づいて，本研究にお いて, 両多様性の有意な線形回帰モデルを構築して流域 内の遺伝的多様性空間分布を推定した. 本研究のHSI種 多様性は広域環境データから算定されている. 従って, HSI種多様性より流域全域に渡る連続的なウルマーシマ トビケラの遺伝的多様性を表現可能と考える. また, 構 築された遺伝的多様性空間分布予測手法の適用可能性に ついて考察した.

\section{2. 方法}

\section{（1）研究対象流域}

名取川水系は宮城県の中央部に位置し，流域面積 939 $\mathrm{km}^{2}$ を有する（図-1）。上流域は標高1,000mを越え る山岳地帯のため冬季は多くの積雪があり, 中流域は仙 台市を中心とした市街地を有し, 下流域は水田地帯が広 がる.また，大型の多目的ダムである大倉ダムと釜房ダ ムは，それぞれ広瀬川の支川である大倉川と，名取川の 支川である碁石川において設置されている.

\section{（2）HSI算定に使用した物理環境データ}

第5回自然環境保全基礎調査（平成5年 10 年度）の植 生調査結果から作成された植生区分データを植生データ として利用した. 国土数值情報の宮城県土地利用格子 データ（平成3年）を土地利用データとして使用した.

解像度 $50 \mathrm{~m}$ 標高マップからメッシュごとの勾配を計 算した。市街化率は，土地利用マップの建物用地と幹線 交通用地を市街地と仮定して算定した. 市街地, 森林ま での距離マップは土地利用マップを基に作成した. 計算 対象メッシュから最寄りの市街地および森林までの距離 を求め, 対象メッシュの值とした. 同様にして, 河道 マップおよび地勢図より水辺までの距離マップを作成し た. 本研究においては, 河道および田を水辺と定義した. 名取川流域の1999年7月から 2000 年6月の 1 年間におけ る日毎水深・流速を分布型流出モデル14) を使用して計 算した. 入力データである気温, 降水量等の流域内分布 データは，仙台，川崎，新川の3地点のアメダス観測所 におけるデータから重みつき距離平均法により求めた. 本モデルは，大きく河道部と斜面部の二つに分けられる. 斜面部をさらに直接流層，基底流層，積雪・融雪層の3 層に分けて計算しており，それぞれkinematic wave法, 貯留関数法, degree-day法を用いている. 河道部におい てdynamic wave法を用いている.

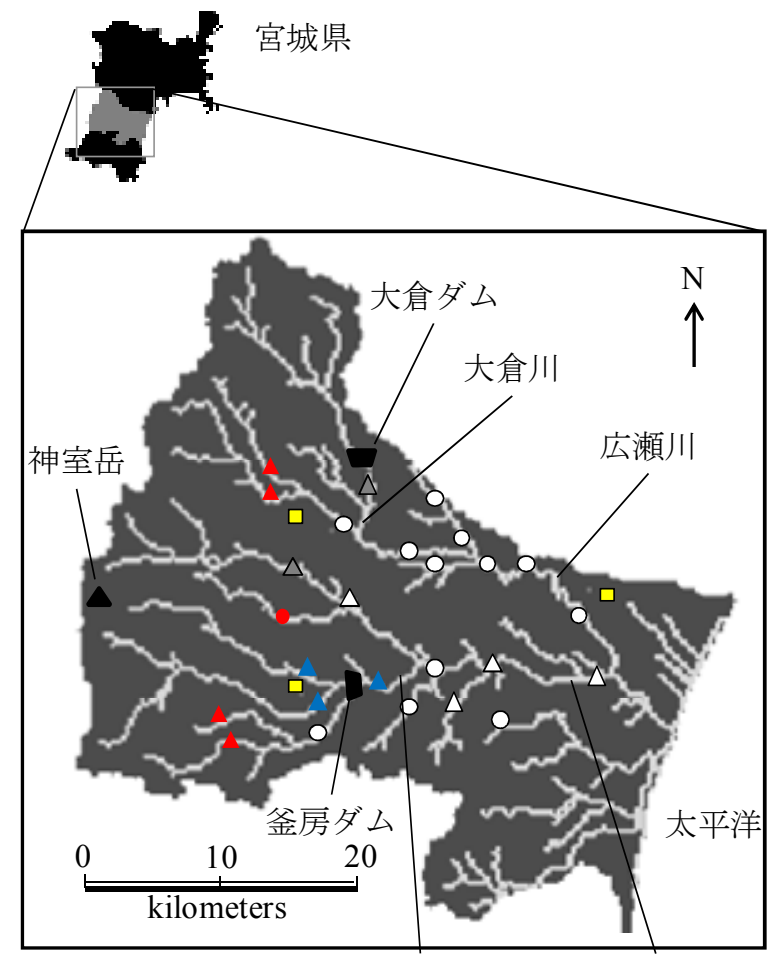

碁石川

名取川

\begin{tabular}{|c|c|}
\hline$\bigcirc$ & 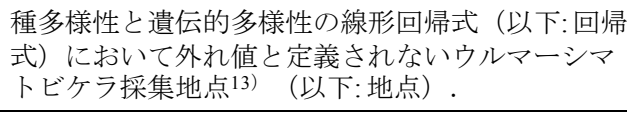 \\
\hline$\triangle$ & $\begin{array}{l}\text { 回帰式において外れ值と定義された地点. 灰塗の } \\
\text { プロットは回帰式において有意な外れ値 } \\
(\mathrm{P}<0.05) \text { とされた地点13). }\end{array}$ \\
\hline$\square$ & アメダス観測所 \\
\hline
\end{tabular}

赤塗のプロットはウルマーシマトビケラ生息地点における 最上流端かつその上流にシロズシマトビケラが生息してい る地点. 青塗のプロットは釜房ダムの直上・直下 (半径 $2 \mathrm{~km}$ 圈内）の地点.

図-1 調査流域とウルマーシマトビケラ採集地点

\section{（3）種多様性}

\section{a） 対象生物}

対象とした生物は，異なる環境を選好する分類群とし て止水性トンボ，流水性トンボ，メダカ，ゲンジボタル， ヘイケボタル, カエル類である. 本生物データは, 名取 川流域下流部に位置寸る名取市による2000～2001年の生 物調查結果 ${ }^{15}$ を使用している。これは，解像度 $250 \mathrm{~m}$ メッシュの範囲において生息の有無を生態学の専門家が 種を特定し，全1231種の動物を確認したものである. カ エル類は, サンプル数が多く生息環境が類似しているニ ホンアカガエル, トウキョウダルマガエル, ツチガエル をまとめて一つの分類群とした.

\section{b) HSIモデル}

HSIモデルの構築について, 始めに環境指標ごとに生 物のSI（Suitability Index）モデルを作成した.メッシュ 内の生物調査データと環境指標データにより対象生物に おける環境指標ごとの頻度分布図を作成し，これの頻度 の最大值が1.0となるように基準化してSIとした．SI值は 0.0 (不適) 1.0 (最適) の間の数値により表現される. 
本研究において用いた環境指標は，(1)水深(年平均・年 最大・年最小・年間変動の分散), (2)流速(年平均・年最 大・年最小・年間変動の分散), (3)勾配, (4)土地利用, (5)植生，(6)市街化率，(7)市街地までの距離，(8)森林ま での距離, (9)水辺からの距離である. (1)〜(3)は河道に おいてのみ，その他の指標については，流域内全域にお いて值を有する. 算出した全環境指標のSIを以下の式よ り相乗平均してHSIを求めた。

$$
H S I=\sqrt[p]{\prod_{j=1}^{p} S I_{j}}
$$

ここで, $S I_{j}$ : 環境指標 $j$ 生息適性指数, $p$ : 環境指標の 数である. HSIもSIと同様に0.0, 1.0 がそれぞれ対象生物 に不適，最適な值である。

\section{c）種多様性の算定}

HSIから算定した分類群数を種多様性として使用した. HSIの数值が高いほど対象生物の適性度は高い。この観 点より，あるメッシュ $(x, y)$ において $H S I_{x y} \geqq 0.5$ となる 場合に対象生物が「存在」すると仮定し $S_{x y l}=1$ とし, $H S I_{x y}<0.5$ となる場合は対象生物が「不在」と仮定して $S_{x y l}=0$ とした. ここで $S_{x y i}$ は $(x, y)$ における分類群iの 「存在（1）」「不在（0）」を表している.これにより， $S_{x y}=\sum_{\mathrm{i}=1}^{\mathrm{n}} S_{x y i}$ より分類群数Sを算出した. 本研究にお いて対象としているメッシュサイズは $250 \mathrm{~m}$ であるため, 分類群数分布 $(50 \mathrm{~m}$ メシュ) の $250 \mathrm{~m} \times 250 \mathrm{~m}$ の值を $\overline{\mathrm{S}}$


はその值を平均分類群数 $\overline{\mathrm{S}}$ と呼ぶ. 風間ら ${ }^{9}$ によると $H S I$ により算定された種多様性とオオタカのHSIの空間的な 分布傾向が酷似している. オオタカを含む猛禽類は生態 系ピラミッドの頂点に位置しその生態系における種多様 性を表現する指標とされる ${ }^{16}$ 。これより, 本研究におけ るHSI（生息ポテンシャル）に基づいて水生生物の種数 を推定することが出来ると考えられる.

\section{（4）遺伝的多様性}

遺伝的多様性の算定対象種であるウルマーシマトビケ

ラ (Hydropsyche orientalis) のサンプリングは名取川流 域における全26か所の調査地点において2006年10月～11 月に行われた（図-1）。本研究において，このサンプル を用いてAFLP分析により検出されたDNA多型を基に計 算された遺伝的多様性データ (未発表, Watanabe, Omura, Monaghan）を使用している。本種は名取川流域におい てしばしば優占種となる造網型トビケラである。

各幼虫個体からDNAをフェノール抽出し, 既報 ${ }^{11)}$ 従いAFLP Plant Mapping Kit (Applied Biosystems)による AFLP分析を行った. PCR産物を, ABI PRISM® 3130xl Genetic Analyzer (Applied Biosystems) を用いて塩基長ご とに分類した. フラグメント解析にはソフトウェア Gene Mapper (Applied Biosystems) を使用した. 本デー タよりへテロ接合度 $\mathrm{H}_{\mathrm{e}}$ をAFLP-SURV ver. 1.0を使用して
表-1 糠澤ら ${ }^{13)}$ の場合と2地点の外れ值を除外した場合のHSI 種多様性 (平均分類群数 $\bar{S}$ ) と遺伝的多様性指標における

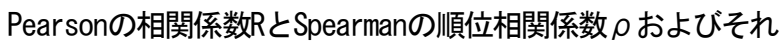
ぞれの相関分析におけるP値

\begin{tabular}{lccc}
\hline & $\mathrm{H}_{\mathrm{e}}$ & $\theta_{\mathrm{S}}$ & $\theta_{\pi}$ \\
\hline \hline 糠澤 $^{13)}$ & & & \\
\hline Pearsonの相関係数 $\mathrm{R}$ & 0.34 & $\mathbf{0 . 4 5}$ & 0.39 \\
P值 & 0.09 & $<\mathbf{0 . 0 5}$ & 0.05 \\
\hline Spearmanの順位相関係数 $\rho$ & $\mathbf{0 . 4 0}$ & $\mathbf{0 . 4 9}$ & $\mathbf{0 . 4 3}$ \\
P值 & $<\mathbf{0 . 0 5}$ & $<\mathbf{0 . 0 5}$ & $<\mathbf{0 . 0 5}$ \\
\hline 有意な外れ值除外 & & & \\
\hline Pearsonの相関係数R & 0.35 & $\mathbf{0 . 4 9}$ & $\mathbf{0 . 4 1}$ \\
P值 & 0.09 & $<\mathbf{0 . 0 5}$ & $<\mathbf{0 . 0 5}$ \\
\hline Spearmanの順位相関係数 $\rho$ & $\mathbf{0 . 4 1}$ & $\mathbf{0 . 5 1}$ & $\mathbf{0 . 4 5}$ \\
P值 & $<\mathbf{0 . 0 5}$ & $<\mathbf{0 . 0 1}$ & $<\mathbf{0 . 0 1}$ \\
\hline
\end{tabular}

$\mathrm{H}_{\mathrm{e}}=1-\sum \mathrm{p}_{\mathrm{i}}^{2}$ より算出した ${ }^{17)}$. ここで, $\mathrm{p}_{\mathrm{i}}$ は墦目の遺伝子座 における遺伝子頻度である. AFLP分析においては一つ の遺伝子座における対立遺伝子数を 2 種類と仮定してい る. ハーディ・ワインベルク平衡を仮定して遺伝子頻度 はZhivotovsky ${ }^{18)}$ に従いベイズ的アプローチにより計算し ている. 集団より無作為に抽出した2個の平均塩基相違 数 (塩基多様度) $\pi$ の期待值である集団突然変異率 $\theta_{\pi}{ }^{19)}$ と多型遺伝子座の割合Sの期待值である集団突然変異率

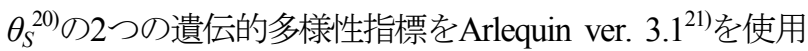
して算出した. $\theta_{S}$ と $\theta_{\pi}$ はを有効集団サイズ， $\mu$ を代あ たり遺伝子座あたりの突然変異率として以下の式より求 められる.

$$
\begin{aligned}
& E(\pi)=\theta_{\pi}=4 N \mu \\
& E(S)=\theta_{S} \sum_{i=1}^{n-1} \frac{1}{i}
\end{aligned}
$$

\section{（5）遺伝的多様性空間分布の推定}

平均分類群数と遺伝的多様性の散布図において, 糠澤 ら ${ }^{13}$ において有意な外れ值と定義された2個体群を除外 した. その後, 統計的有意な関係性を有していた散布図 において，遺伝的多様性を目的变数とする単回帰モデル を構築した。 これにより, 流域内の河道における遺伝的 多様性空間分布を連続的に推定した.

\section{3. 結果}

表-1に, 平均分類群数 $\overline{\mathrm{S}}$ と遺伝的多様性3指標におけ るPearsonの相関係数RおよびSpearmanの順位相関係数 の結果について, 糠澤ら ${ }^{13)}$ の結果と, 有意な外孔值2個 

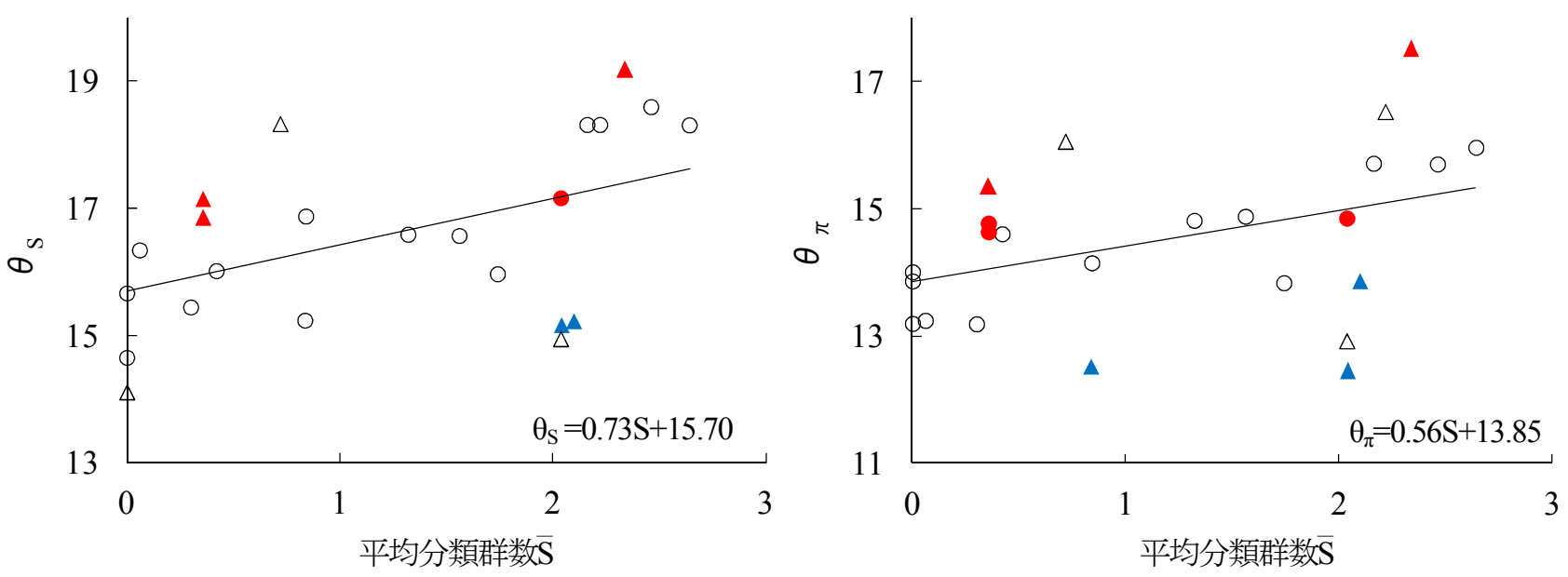

図-2 平均分類群数 $\bar{S}$ と, $\theta_{S}(\mathrm{R}=0.49, \mathrm{P}<0.05) ， \theta_{\pi}(\mathrm{R}=0.41, \mathrm{P}<0.05)$ の散布図と回帰式. 三角形のプロットは残差（外れ 值）において20\%上位のものを示す．赤の中塗はウルマーシマトビケラ生息地点における最上流端かつその上流にシロズシマトビ ケラが生息している地点である. 青の中塗は釜房ダムの上流・下流2km圏内の地点である.

体群を除外した場合の結果を示す．平均分類群数とへテ 口接合度 $\mathrm{H}_{\mathrm{e}} \quad(\rho=0.41, \mathrm{P}<0.05)$ および $\theta_{\mathrm{S}} \quad(\mathrm{R}=0.49$, $\mathrm{P}<0.05 ; \rho=0.51, \mathrm{P}<0.01), \theta_{\pi} \quad(\mathrm{R}=0.41, \mathrm{P}<0.05 ; \rho=0.45$, $\mathrm{P}<0.01 ）$ に既報における解析よりもそれぞれ強い有意な 正の相関関係が確認された. Pearsonの相関係数Rにおい て平均分類群数と有意な相関を示した遺伝的多様性2指 標 $\left(\theta_{\mathrm{S}}\right.$ と $\left.\theta_{\pi}\right)$ における散布図と相関係数, 推定された回 帰式を図-2に示した。

平均分類群数と $\theta_{\mathrm{S}} \quad\left(\theta_{\mathrm{S}}=0.73 \mathrm{~S}+15.70\right), \theta_{\pi}$ $\left(\theta_{\pi}=0.56 \mathrm{~S}+13.85\right)$ の回帰式より, 平均分類群数から予 測した $\theta_{\mathrm{S}}$ と $\theta_{\pi}$ の流域内における空間分布困（以下，遺伝 的多様性分布図）を作成した. 例として図-3に $\theta_{\mathrm{S}}$ 分布図 を示す． $\theta_{\pi}$ の分布図においては， $\theta_{\mathrm{S}}$ の空間分布と同様の パターンを示したため, 本稿においては割愛した. 分布 図における河道の標高 (0-910m) をデータ数が偏り過 ぎないように6範囲に分類し，それぞれの範囲における $\theta_{\mathrm{S}}$ の平均值および標準誤差を図-4に示した.

\section{4. 考察}

HSI種多様性が高い生息場において，環境異質性が高 く, 多様な水生生物種の移入・定着ポテンシャルが高い とされる ${ }^{13)}$. 従って, 目的変数を遺伝的多様性, 説明変 数をHSI種多様性とした線形回帰式は，環境の多様さや 種の移入・定着が活発になるほど遺伝的多様性が高まる 関係を表すモデルと言える。この回帰式において，HSI 種多様性が0の場合に遺伝的多様性は0にならず一定の值 を有する．これは，HSI種多様性が0の場所にウルマー シマトビケラ個体群が定着した場合に有するオリジナル の遺伝的多様性の值を表現していると言える.

糠澤ら ${ }^{13)}$ においてはHSI種多様性と遺伝的多様性の散 布図において2地点の外れ值が確認されている.この外 れ值は, 既往研究2)における種多様性と遺伝的多様性に

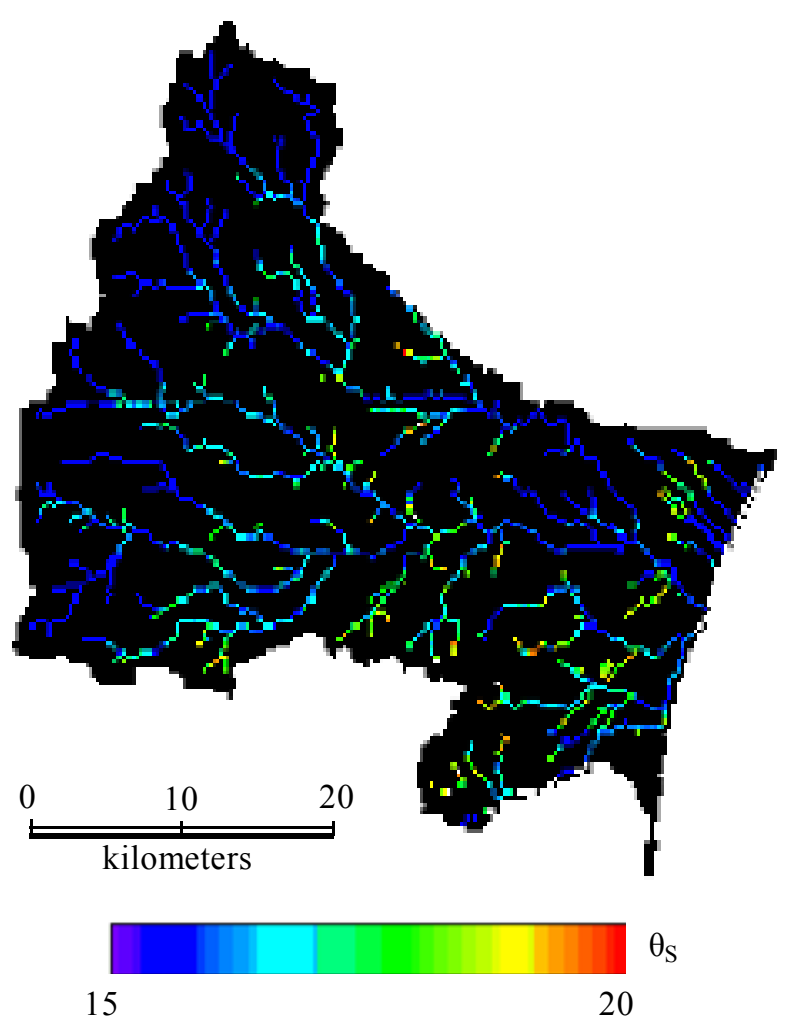

図-3 遺伝的多様性分布図 $\left(\theta_{\mathrm{S}}\right)$

独立して影響する2要因（環境異質性，移入・定着ポテ ンシャル）とは別のHSI種多様性と関連付けることが出 来ない外因的要素（ダムによる個体群間交流の阻害, ニッチェが競合する近縁種との交雑）の影響があると考 えられる. 以上より，本研究においてこれら外れ值を除 外して回帰モデルを構築した．2個体群の外れ值を除外 したHSI種多様性と遺伝的多様性の3指標は糠澤ら ${ }^{13)}$ の解 析よりも一貫して強い正の相関を示した（表-1）。従っ て，全地点のサンプルを用いた場合と比較して，外れ值 を除外した線形回帰式はより精度良くHSI種多様性の変 動に応答して遺伝的多様性を推定出来る. 


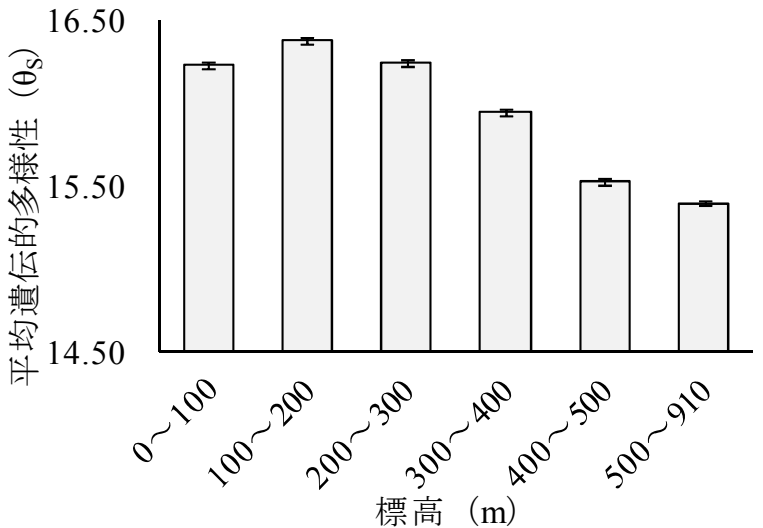
図-4 標高ごとの遺伝的多様性 $\left(\theta_{S}\right)$ の平均値. バ一は標準
誤差を示す.

図-2をみると，上位 $20 \%$ の外れ值（三角形のプロット） にも他の地点とは異なる外因的条件が確認された. 赤塗 のプロットにて示された地点はウルマーシマトビケラ生 息地点の最上流端かつその上流にシロズシマトビケラが 生息している地点（以下：最上流地点）である. 多くの 最上流地点におけるウルマーシマトビケラの遺伝的多様 性は，上流からの同種個体群との遺伝子交流が相対的に 少ないと考えられるため, 低く表現されると予想してい たが，これに反して，実際は高い外れ值として表現され ていた.これは，上流の近縁種との交雑や水温における 環境適応の影響 (未発表, Nukazawa, Kazama, Watanabe) による遺伝的多様性の変動が要因と推測される. 青塗の プロットは釜房ダムの上流・下流 $2 \mathrm{~km}$ 圈内の地点を表し ている.これは, 釜房ダムの下流 $2 \mathrm{~km}$ 程度の地点におい て上流・下流個体群へのダム下流・上流加の個体群の 移住が制限され，遺伝子供給量が減少することに起因す ると考える. 以上の結果は糠澤ら ${ }^{13)}$ の考察を支持するも のである. しかし，上位 $20 \%$ 外れ值の地点においては， HSI種多様性により表現できない要素が影響して遺伝的 多様性を増加させている可能性がある一方, 統計的有意 な外れ值ではないため, 回帰モデル構築に際して除外し ていない.

遺伝的多様性空間分布図（図-3）に関して，中流域と 支流において多様性が高く表現された. 図-4において, 0〜300mの範囲にて平均遺伝的多様性は増加している.

特にHSI種多様性が高い值を示した標高100〜200m付近 の中流域にて遺伝的多様性は増加した. Watanabeら ${ }^{22}$ に おける観測データの縦断分布においてもウルマーシマト ビケラの遺伝的多様性は名取川中流域において高く表現 されている. このため, 本分布はこの傾向を表現出来て いると言える. 本種は河床が石碩により構成される流速 の早い場所に生息することが知られている23. このため, 規模の大きい河川主流の下流のように流れが遅く水深の 深い場所よりも小規模かつ瀬の多く存在する支流を生息 場として好むと考えられる. 支流を生息場として選好す る特徵はHSI算定の対象種であるゲンジボタルや流水性
トンボとも類似している.このため, 類似した生息環境 を好む水生生物の生息ポテンシャルが相対的に高い場所 においてウルマーシマトビケラ遺伝的多様性の高まる事 実が示唆された。

名取川や広瀬川などの主流における遺伝的多様性は支 流に比べて低く表現された。これは，主流と支流の時空 間的なHSI種多様性の違いに起因して変化した可能性が 高い，すなわち，河川主流は出水の影響を支流より受け 易いため, 本種の安定した移入と営巣活動が相対的に困 難なことが原因と考える. また，名取川と広瀬川の下流 および合流地点付近においても遺伝的多様性は低く表現 された. この領域は河道が仙台市の市街地に覆われてい て, 河川改修により瀬や淵なじ河川が本来有する多様な ハビタットが消失している. このため, 河川の環境異質 性が低下してHSI種多様性が減少したことに起因して遺 伝的多様性が低下したと考えられる，また，主流におい て，出水による大きい流速の影響を相対的に受けにくい と考えられるサイズの大きい種群の造網型トビケラ（例 えば，ヒゲナガカワトビケラ (Stenopsyche marmorata)) の生息密度が増加した結果，ギルドを同じくする本種の 遺伝的多様性が減少した可能性がある.

\section{5. まとめ}

糠澤ら ${ }^{13)}$ の分析における有意な外れ值2個体群を除外 して計算した平均分類群数 $\mathrm{S}$ と遺伝的多様性3指標にお けるPearsonの相関係数およびSpearmanの順位相関係数 を評価した. また，Pearsonの相関係数において高い值 を示した平均分類群数と $\theta_{\mathrm{S}}$ と $\theta_{\pi}$ の線形回帰式を構築した. これらの回帰式に基づいて，流域全域の河川におけるウ ルマーシマトビケラ個体群の空間的な遺伝的多様性分布 を連続的に提示した. 得られた主な結果及び考察を以下 に示す.

1）平均分類群数とへテロ接合度 $\mathrm{H}_{\mathrm{e}} \quad(\rho=0.41, \mathrm{P}<0.05)$ および $\theta_{\mathrm{S}} \quad(\mathrm{R}=0.49, \mathrm{P}<0.05 ; \rho=0.51, \mathrm{P}<0.01) ， \theta_{\pi}$

$(\mathrm{R}=0.41, \mathrm{P}<0.05 ; \rho=0.45, \mathrm{P}<0.01)$ には糠澤ら $\left.{ }^{13}\right)$ における 解析よりも強い有意な正の相関関係が確認された.

2）予測された遺伝的多様性は中流域と支流において遺 伝的多様性が高いパターンを示した. 既往の遺伝的多様 性の縦断分布に関する報告と比較すると，この分布傾向 は妥当なものであると言える.

3) HSI種多様性と遺伝的多様性の関係式により, 流域全 域における遺伝的多様性空間分布の推定を可能とした.

遺伝的多様性空間分布図は河道におけるウルマーシマ トビケラの連続的な遺伝的多様性を表現している.この ため, 観測地点が不足している場合や実測が困難な場所 においても多様性を推定出来る. HSI種多様性は異なる 環境を好む水生生物に適した環境を総合的に表現してい 
る指標であると言える. このため, HSI種多様性と遺伝 的多様性の関係性より遺伝的多様性を推定する本研究の 手続きを利用することにより，ダム撤去や気候変動に伴 う水理条件の変化, 都市計画やゾーニングによる土地利 用の変化が種多様性のみならず遺伝的多様性に与える影 響を推定出来る.

本研究において，止水性トンボ，流水性トンボ，メダ カ, ゲンジボタル, ヘイケボタル, カエル類のHSIを種 多様性の算定に使用している. これらの種は生態系の中 において選好する生息条件やニッチェが異なる ${ }^{24)}$ た, HSIにおいて種多様性を表現出来ると考える.このため, 6種から推定されたHSI種多様性から一般的な淡水生物 の種多様性を表現可能と考えている. しかしながら，よ り実際の状態に近い淡水生物の種多様性を表現するため にはより多くの生物種のHSIを使用することが望ましい， また, 今後は遺伝的多様性の評価対象種を, キーストン 種や固有種, 絶滅危惧種を中心として増やすことが生物 多様性保全の観点から望ましいと言える.

謝辞：本研究は, 科学研究費補助金 (22360192, 代表 : 風間聡) と科学研究費補助金 (30111248, 代表 : 大村達 夫）の助成を受けたものである. 併せてここに深甚なる 謝意を表します。

\section{参考文献}

1) Convention on Biological Diversity: http://www.cbd.int/

2) Vellend M. and Geber M.A.: Connections between species diversity and genetic diversity, Ecology Letters, Vol.8, pp.767781, 2005.

3) Manel S., Schwartz MK., Luikart G. and Taberlet P.: Landscape genetics: combining landscape ecology and population genetics. Trends in Ecology and Evolution, Vol.18 (4), pp.189-197, 2003.

4) Jump AS., Hunt JM., Martinez-Izquierdo JA. and Penuelas J.: Natural selection and climate change: temperature-linked spatial and temporal trends in gene frequency in Fagus sylvatica. Molecular Ecology, Vol.15, pp.3469-3480, 2006.

5) Mariac C., Jehin L., Saidou A.-A., Thuillet A.-C., Couderc M., Sire P., Jugde H., Adam H., Bezancon G., Pham J.-L. and Vigouroux Y.: Genetic basis of pearl millet adaptation along an environmental gradient investigated by a combination of genome scan and association mapping. Molecular Ecology, Vol.20, pp.80-91, 2011.

6) Balkenhol N. and Landguth EL:: Simulation modelling in landscape genetics: on the need to go further. Molecular Ecology, Vol.20, pp.667-670, 2011

7) 糠澤桂, 白岩淳一, 風間聡: 河川水温を考慮したHSIモデル による水生生物の生息環境評価, 水工学論文集, 第55巻, pp.1255-1260, 2011.

8）知花武佳, 玉井信行: 生息域の季節変動に着目した魚類生 息域適性基準に関する研究, 水工学論文集, 第46巻, pp.1145-1150, 2002.
9) 風間聡, 松本哲, 沢本正樹, 浜本洋: HSI モデルによる生物 生息場推定を利用した流域環境評価，土木学会論文集 B, Vol.63 (4), pp.338-350, 2007.

10) Berrebi P., Povz M., Jesensek D., Cattaneo-Berrebi G., Crivelli A.J.: The genetic diversity of native, stocked and hybrid populations of marble trout in the Soca river, Slovenia, Heredity, Vol.85, pp.277-287, 2000.

11）渡辺幸三, 菊池祐二, 風間聡, 大村達夫: 東日本の 3 水系 に生息するヒゲナガカワトビケラの遺伝的多様性の空間 階層構造, 水環境学会誌, Vol.31, pp.31-37, 2008.

12）糠澤桂, 風間聡, 渡辺幸三, Kang J.: スリット型砂防ダムの 存在する溪流河川の底生動物の種多様性と遺伝的多様性, 環境工学研究論文集, Vol. 47, pp. 433-439, 2010.

13）棣澤桂, 風間聡, 渡辺幸三: 河川生物のHSI種多様性と遺伝 的多様性の関係性について, 土木学会論文集G（環境）, Vol.68(7), pp.603-610, 2012.

14）土田恭平, 風間聡, 沢本正樹: 河川環境確保のための土地 利用と許容人口の関係, 水工学論文集, 第48巻, pp.475-480, 2004.

15）名取市: 名取市環境基本計画策定基礎資料IV動植物調查報 告書, 2002.

16）山崎亨: 猛禽頑が自然保護活動の中で注目されるわけ「猛 禽類でわかる生態系の健全度」, 月刊「自然保護」, No.408, 1996.

17) Vekemans X., T. Beauwens, Lemaire M. and Roldan-Ruiz I.: Data from amplified fragment length polymorphism (AFLP) markers show indication of size homoplasy and of a relationship between degree of homoplasy and fragment size, Molecular Ecology, Vol.11, pp.139-151, 2002.

18) Zhivotovsky LA.: Estimating population structure in diploids with multilocus dominant DNA markers, Molecular Ecology, Vol.8, pp.907-913, 1999.

19) Watterson, G.: On the number of segregating sites in genetical models without recombination, Theoretical Population Biology, Vol.7, pp.256-276, 1975.

20) Tajima F.: Evolutionary relationship of DNA sequences in finite populations, Genetics, Vol.105, pp.437-460, 1983.

21) Excoffier L., Lavel G. and Schneider S.: Arlequin ver.3.1 : an integrated software package for population genetics data analysis, Evolutionary Bioinformatics Online, Vol.1, pp.47-50, 2005.

22) Watanabe K., Monaghan MT. and Omura T.: Longitudinal patterns of genetic diversity and larval density of the riverine caddisfly Hydropsyche orientalis (Trichoptera), Aquatic Science, Vol.70, pp.377-387, 2008.

23）柴谷篤弘, 谷田一三: 日本の水生昆虫, 東海大学出版会, 1989.

24）風間聡, 松本哲, 沢本正樹: 数值地図情報ならびに水文モ デルデータを用いたHSIモデルによる生物生息域の推定, 土木学会論文集B, Vol.63 (4), pp.323-337, 2007.

(2012. 9. 30受付) 